Piotr KORDEL

Krzysztof KORDEL

Marek SAJ

Poznań

\title{
Działalność samorządu lekarskiego w zakresie doskonalenia zawodowego na przykładzie Wielkopolskiej Izby Lekarskiej
}

J ednym z samorządów zawodowych działających w Polsce są izby lekarskie. Zrzeszają one w swoich szeregach lekarzy i lekarzy dentystów. Izby lekarskie funkcjonują na dwóch szczeblach - okręgowych izb lekarskich, które tworzą lekarze wpisani na listy ich członków oraz Naczelnej Izby Lekarskiej, której organy konstytuują się z delegatów wybieranych podczas okręgowych zjazdów lekarzy. Zadaniami, jakie ustawodawca postawił przed samorządem lekarskim były:

— sprawowanie pieczy i nadzoru nad należytym i sumiennym wykonywaniem zawodu lekarza;

- ustanawianie obowiązujących wszystkich lekarzy zasad etyki i deontologii zawodowej oraz dbałość o ich przestrzeganie;

- reprezentowanie i ochrona zawodu lekarza;

— integrowanie środowiska lekarskiego;

- zajmowanie stanowiska w sprawach stanu zdrowotności społeczeństwa, polityki zdrowotnej państwa oraz organizacji ochrony zdrowia;

— współpraca z towarzystwami naukowymi, szkołami wyższymi i jednostkami badawczo-rozwojowymi w kraju i za granicą;

— prowadzenie instytucji samopomocowych i innych form pomocy materialnej dla lekarzy i ich rodzin;

— zarządzanie majątkiem i działalnością gospodarczą izb lekarskich ${ }^{1}$.

Jak widać z powyższego zestawienia zadań izb lekarskich, połowa z nich dotyczy samego samorządu i interesów jego członków (reprezentowanie i ochrona zawodu lekarza, integrowanie środowiska lekarskiego, prowadzenie instytucji samopomocowych i innych form pomocy materialnej dla lekarzy i ich rodzin, zarządzanie majątkiem i działalnością gospodarczą izb lekarskich). Druga połowa (sprawowanie pieczy i nadzoru nad należytym i sumiennym wykonywaniem zawodu lekarza, ustanawianie obowiązujących wszystkich lekarzy zasad etyki i deontologii zawodowej oraz dbałość o ich przestrzeganie, zajmowanie stanowiska w sprawach stanu zdrowotności społeczeństwa, polityki zdrowotnej państwa oraz organizacji ochrony zdrowia, współpraca z towarzystwami naukowymi, szkołami wyższymi i jednostkami badawczo-rozwojowymi w kraju i za granicą) w sposób bezpośredni lub pośredni wiąże się z zapewnieniem bezpieczeństwa pacjentów korzystających z usług świadczonych przez lekarzy. Można zatem stwierdzić, że w pełni realizuje zapisy art. 17 ust. 1 Konstytucji RP z dnia 2 kwietnia 1997 r., który stanowi, iż w drodze ustawy można tworzyć

\footnotetext{
${ }^{1}$ Art. 4 ust. 1 ustawy z dnia 17 maja 1989 r. o izbach lekarskich (Dz. U. 1989, Nr 30 poz. 158).
} 
samorządy zawodowe, reprezentujące osoby wykonujące zawody zaufania publicznego i sprawujące pieczę nad należytym wykonywaniem tych zawodów w granicach interesu publicznego i dla jego ochrony.

W ramach realizacji pierwszego zadania z powyższej listy, tj. sprawowania pieczy i nadzoru nad należytym i sumiennym wykonywaniem zawodu, mieszczą się takie działania izb lekarskich, jak przyznawanie prawa wykonywania zawodu, prowadzenie rejestrów lekarzy i prywatnych praktyk, a także działania w zakresie doskonalenia zawodowego lekarzy, które ze względu na dynamikę zmian w medycynie, powstawanie nowych technologii i stosowanie nowatorskich rozwiązań i leków stało się priorytetem dla samorządu lekarskiego.

Doskonalenie zawodowe lekarzy i lekarzy dentystów rozpatrywane jest na kilku płaszczyznach. Po pierwsze z perspektywy instytucji wykonującej zadania administracji publicznej, kiedy doskonalenie zawodowe traktowane jest jako współdziałanie samorządu zawodowego w sprawach specjalizacji zawodowej ${ }^{2}$. Po drugie z perspektywy środowiska lekarskiego, kiedy to dotyczy bezpośredniego wsparcia procesu podnoszenia kwalifikacji zawodowych. Uzupełnieniem tych zapisów było umożliwienie współpracy izb lekarskich z towarzystwami naukowymi, szkołami wyższymi i jednostkami badawczo-rozwojowymi w kraju i za granicą. Należy również zastanowić się nad całym systemem doskonalenia zawodowego. Z jednej strony mamy do czynienia z procesem zdobywania kwalifikacji zawodowych lekarzy i lekarzy dentystów w formie odbywania stażu podyplomowego, który dotyczy młodych adeptów zawodu lekarza kończących proces zdobywania wiedzy na studiach i posiadających ograniczone prawo do wykonywania zawodu, co szczegółowo reguluje stosowne rozporządzenie Ministra Zdrowia, wydane po zasięgnięciu opinii Naczelnej Rady Lekarskiej ${ }^{3}$ oraz procesu specjalizacji, czyli uzyskiwania uprawnień do posługiwania się tytułem lekarza specjalisty ${ }^{4}$, a z drugiej strony proces podnoszenia kwalifikacji zawodowych w celu maksymalizacji możliwości wykonywania zawodu. Zagadnienie to w bardzo jasny sposób definiuje art. 2 ust. 1 Rozporządzenia Ministra Zdrowia z dnia 6 października 2004 r. w sprawie sposobów dopełnienia obowiązku doskonalenia zawodowego lekarzy i lekarzy dentystów (Dz. U. 2004, $\mathrm{Nr} 231$, poz. 2326), który mówi, że: doskonalenie zawodowe lekarza obejmuje aktywność zawodowa $w$ ramach samokształcenia lub $w$ zorganizowanych formach ksztatcenia podyplomowego poprzez odbywanie szkolenia specjalizacyjnego [...], nabywanie umiejętności zawodowych z zakresu węższych dziedzin medycyny lub udzielania określonych świadczeń zdrowotnych [...] oraz doskonalenie $w$ innych formach ksztatcenia.

Potwierdzeniem znaczenia tego procesu było wpisanie przez ustawodawcę tego zagadnienia do przyjętej w dniu 15 grudnia 1996 r. ustawy o zawodzie lekarza (Dz. U. 1997, Nr 28, poz. 152), gdzie zapisano, że lekarz ma prawo i obowiązek doskonalenia zawodowego, w szczególności w różnych formach kształcenia podyplomowego ${ }^{5}$. Sposób dopełnienia tego ustawowego obowiązku określa minister zdrowia, po zasięgnięciu opinii Naczelnej Izby Lekarskiej, w drodze rozporządzenia - art. 18 ust. 2 przywołanej wyżej ustawy. Naczelna Rada Lekarska wydaje jeszcze przepisy szczegółowe odnośnie liczby punktów za wydarzenie o charakterze edukacyjnym w postaci uchwał, takich jak Uchwała nr 013/97/00/III z dnia 14 kwietnia 2000 r. Naczelnej Rady Lekarskiej w sprawie określenia sposobu dopełnienia obowiązku doskonalenia zawodowego przez lekarzy. Dodatkowym potwierdzeniem stałej obecności i znaczenia

${ }^{2}$ Art. 4 ust. 2 pkt 4 ustawy z dnia 17 maja 1989 r. o izbach lekarskich (Dz. U. 1989, Nr 30, poz. 158).

${ }^{3}$ Art. 15 ust. 5 pkt 1-7 ustawy z dnia 5 grudnia 1996 r. o zawodzie lekarza (Dz. U. 1997, Nr 28, poz. 152).

${ }^{4}$ Art. 4 ust. 2 pkt 4 ustawy z dnia 17 maja 1989 r. o izbach lekarskich (Dz. U. 1989, Nr 30, poz. 158).

${ }^{5}$ Art. 18 ust. 1 ustawy z dnia 5 grudnia 1996 r. o zawodzie lekarza (Dz. U. 1997, Nr 28, poz. 152). 
samorządu lekarzy i lekarzy dentystów w doskonaleniu zawodowym środowiska lekarskiego jest zapis art. 19 ww. ustawy, który uzależnia prawo do organizacji i prowadzenia szkoleń dla lekarzy i lekarzy dentystów od pozytywnej decyzji wyrażonej przez właściwą okręgową radę lekarską okręgowej izby lekarskiej. Zapis ten nie stracił na ważności po jego uchwaleniu, doczekując się z czasem doszczegółowienia i rozszerzenia treści art. 19, które nastąpiło w nowelizacji z dnia 10 kwietnia 2003 r. Odbyło się ono przy okazji dostosowywania przepisów krajowych do wymogów członkostwa w Unii Europejskiej. Wtedy też wyliczono dokładnie katalog weryfikacyjny dla oceny fachowości podmiotów ubiegających się o prowadzenie kształcenia podyplomowego lekarzy. I tak wprowadzono kryteria takie jak: sposób realizacji kształcenia, kadra prowadząca kształcenie, baza dydaktyczna, w tym szkolenia praktyczne, rodzaj i liczba udzielanych świadczeń zdrowotnych oraz posiadanie wewnętrznego systemu jakości kształcenia ${ }^{6}$. Skutkuje to profesjonalizacją rejestrów podmiotów kształcących prowadzonych przez okręgowe izby lekarskie, a także eliminuje z rynku podmioty, których poziom jest poniżej przeciętnej i ich oferta nie odpowiada zapotrzebowaniu środowiska.

Istotną rolę $\mathrm{w}$ procesie ustawicznego kształcenia podyplomowego lekarzy miało dostosowywanie polskiego prawodawstwa do norm i wytycznych europejskich, zarówno w kontekście przywoływanego wcześniej akcesu do Unii Europejskiej, ale i członkostwa Polski w wielu branżowych organizacjach międzynarodowych czy udziału przedstawicieli samorządu lekarskiego w międzynarodowych towarzystwach naukowych. Nie oznacza to jednak, że do czasu przystapienia Polski do Unii Europejskiej polski lekarz nie miał obowiązku podnoszenia kwalifikacji. Na Ministrze Zdrowia ciążył bowiem obowiązek wydawania aktów wykonawczych, których zadaniem było regulowanie sposobu dopełnienia konieczności kształcenia ustawicznego, co zostało zrealizowane m.in. w dniu 6 października 2004 r. w sprawie sposobów dopełnienia obowiązku doskonalenia zawodowego lekarzy i lekarzy dentystów (Dz. U. 2004, Nr 231, poz. 2326).

Nie należy także zapomnieć, że art. 56 Kodeksu etyki lekarskiej mówi wprost o powinności każdego lekarza do uzupełniania i doskonalenia posiadanej wiedzy i umiejętności zawodowych, a także do przekazywania ich swoim współpracownikom. Samorząd lekarski w uchwałach Naczelnej Rady Lekarskiej wskazywał sposoby na dopełnienie obowiązku doskonalenia zawodowego i przyjął on, zgodnie z kierunkami Ministra Zdrowia, kilka form i możliwości dopełnienia obowiązku. Minister Zdrowia przyjął bowiem w swoim rozporządzeniu rozliczenie na podstawie przedstawienia punktów edukacyjnych otrzymywanych przez lekarzy z tytułu uczestnictwa w przedsięwzięciach podnoszących kwalifikacje zawodowe. Dopełnienie obowiązku kształcenia podyplomowego rozumie się poprzez zdobycie w okresie rozliczeniowym tj. 48 miesięcy minimum 200 punktów, na podstawie załącznika nr 3 zawierającego m.in. przelicznik wydarzeń o charakterze edukacyjnym, do przywołanego wcześniej przedmiotowego rozporządzenia Ministra Zdrowia. Lekarz może realizować obowiązek kształcenia ustawicznego poprzez:

1) realizowanie programu specjalizacji lub umiejętności;

2) udział w kursie medycznym nieobjętym programem odbywanej specjalizacji lub nabywanej umiejętności;

3) odbycie praktyki klinicznej w krajowym lub zagranicznym ośrodku specjalistycznym;

${ }^{6}$ Art. 1 ust. 1 pkt 13 ustawy z dnia 10 kwietnia 2003 r. o zmianie ustawy o zawodzie lekarza oraz ustawy o zmianie ustawy o zawodzie lekarza oraz o zmianie innych ustaw (Dz. U. 2003, Nr 90, poz. 845). 
4) udział w krajowym lub zagranicznym kongresie, zjeździe, konferencji lub sympozjum naukowym;

5) udział w posiedzeniu oddziału stowarzyszenia działającego jako „kolegium specjalistów” albo „specjalistyczne lekarskie towarzystwo naukowe”;

6) udział w szkoleniu wewnętrznym organizowanym przez zakład opieki zdrowotnej, w którym lekarz udziela świadczeń zdrowotnych, lub przez grupę lekarzy;

7) wykłady lub doniesienia w formie ustnej lub praktycznej na kongresie, zjeździe, konferencji lub sympozjum naukowym;

8) udział w programie edukacyjnym, opartym o zadania testowe, akredytowanym przez towarzystwo naukowe lub kolegium specjalistów;

9) uzyskanie stopnia naukowego doktora, doktora habilitowanego lub tytułu profesora - w zakresie nauk medycznych;

10) napisanie i opublikowanie fachowej książki medycznej, artykułu w fachowym, recenzowanym czasopiśmie lub edukacyjnego programu multimedialnego;

11) napisanie i opublikowanie książki, artykułu lub programu multimedialnego o charakterze popularnonaukowym;

12) przetłumaczenie i opublikowanie fachowej książki medycznej, rozdziału w książce, artykułu w fachowym czasopiśmie medycznym lub edukacyjnego programu multimedialnego;

13) kierowanie specjalizacją lekarzy lub nabywaniem przez lekarzy umiejętności;

14) prowadzenie szkolenia lekarzy stażystów;

15) indywidualna prenumerata fachowego czasopisma medycznego indeksowanego przez filadelfijski Instytut Informacji Naukowej lub Index Copernicus;

16) przynależność do kolegium specjalistów lub towarzystwa naukowego ${ }^{7}$.

Obowiązek doskonalenia zawodowego jest rejestrowany za pomocą wpisów do ewidencji punktów doskonalenia zawodowego - książeczki otrzymanej od okręgowej izby lekarskiej, której jest członkiem. Po zakończeniu okresu rozliczeniowego lekarz przedkłada ewidencję do właściwej izby lekarskiej, której zadaniem jest jej weryfikacja i wpis do dokumentu Prawo Wykonywania Zawodu o dopełnieniu obowiązku doskonalenia zawodowego ${ }^{8}$. Dodatkowo Naczelna Rada Lekarska uznała, że właściwe okręgowe rady lekarskiej powinny wynagradzać lekarzy, którzy wykazali się szczególnym talentem w kształceniu ustawicznym i otrzymali co najmniej 400 punktów w jednym okresie rozliczeniowym ${ }^{9}$. Lekarze, którym nie uda się rozliczyć z ich obowiązku otrzymują stosowną adnotację w rejestrze lekarzy, prowadzonym przez okręgowe izby lekarskie. Samorząd lekarski w swoich korporacyjnych aktach podkreślił, że każdy kandydat na stanowiska kierownicze lub inne stanowisko w zakładach systemu opieki zdrowotnej, czy też występujący o zatrudnienie jako nauczyciel akademicki, występujący o uzyskanie środków finansowych na kształcenie podyplomowe lub pracę naukową, występujący o zmianę warunków zatrudnienia, występujący o zawarcie umowy na udzielenia świadczeń zdrowotnych przedstawia dokument Prawo wykonywania zawodu

\footnotetext{
${ }^{7}$ Załącznik nr 3 do rozporządzenia Ministra Zdrowia z dnia 6 października 2004 r. w sprawie sposobów dopetnienia obowiqzku doskonalenia zawodowego lekarzy i lekarzy dentystów (Dz. U. 2004, Nr 231, poz. 2326).

${ }^{8}$ § 4 ust. 3-4 rozporządzenia Ministra Zdrowia z dnia 6 października 2004 r. w sprawie sposobów dopetnienia obowiazku doskonalenia zawodowego lekarzy i lekarzy dentystów (Dz. U. 2004, Nr 231, poz. 2326).

${ }^{9} \S 3$ ust. 2 uchwały nr 98/04/IV Naczelnej Rady Lekarskiej z dnia 17 grudnia 2004 r. w sprawie doskonalenia zawodowego lekarzy i lekarzy dentystów.
} 
lekarza lub Prawo wykonywania zawodu lekarza dentysty zawierający wpis o dopełnieniu obowiązku doskonalenia zawodowego wraz z liczbą uzyskanych punktów edukacyjnych ${ }^{10}$.

Nie sposób więc nie dostrzec umocowania prawnego i instytucjonalnego doskonalenia zawodowego jako jednej z najważniejszych płaszczyzn aktywności izb lekarskich. Nie tylko odgórne normy prawne, ale i własne, korporacyjne poczucie znaczenia tego zagadnienia doprowadziło do nadania tak znaczącej rangi tego procesu. Troska o bezpieczeństwo pacjenta, zapewnienie komfortu pracy lekarzowi poprzez ciąłe podnoszenie kwalifikacji i umiejętności zawodowych umocowała kształcenie ustawiczne na stałe wśród priorytetów izby lekarskiej, tak Naczelnej, jak i izb okręgowych.

Z dzisiejszej perspektywy należy zauważyć, że prowadzenie działalności szkoleniowej spoczywa przede wszystkim na okręgowych izbach lekarskich. Naczelna Izba Lekarska odpowiada przede wszystkim za merytoryczny nadzór nad treścią i tematyką szkoleń poprzez przydzielanie akredytacji poszczególnym organizatorom zdarzeń edukacyjnych. Problematyką tą zajmuje się formalnie Naczelna Rada Lekarska, która podejmuje stosowne decyzje po zasięgnięciu opinii Ośrodka Doskonalenia Zawodowego Lekarzy i Lekarzy Dentystów Naczelnej Izby Lekarskiej powołanego do życia uchwałą nr 15/08/IV Naczelnej Rady Lekarskiej w dniu 19 września 2008 r. Głównym założeniem jego działalności jest umożliwienie udziału członkom samorządu w bezpłatnych kursach podnoszących kwalifikacje zawodowe, bowiem każda odpłatność za kurs wymaga udzielenia zgody przez Prezydium Naczelnej Rady Lekarskiej ${ }^{11}$. Aby zmotywować okręgowe izby lekarskie do organizacji bezpłatnych szkoleń dwa razy do roku organizowane są konkursy na dotacje na cele szkoleniowe. Okręgowe izby lekarskie składają do Ośrodka Doskonalenia przy NIL wnioski z propozycjami szkoleń i tematyka, które następnie są oceniane, a dzięki którym uzyskać można wsparcie finansowe realizowanych przedsięwzięć do $50 \%$ koniecznych nakładów ${ }^{12}$. Także okręgowe izby lekarskie (choć nie wszystkie) wyodrębniły spośród swoich biur specjalne jednostki organizacyjne - ośrodki doskonalenia zawodowego - których zadaniem jest organizacja szkoleń, współpraca z firmami szkoleniowymi, a także prowadzenie rejestru podmiotów kształcących. W Wielkopolskiej Izbie Lekarskiej taka jednostka powołana została uchwałą Okręgowej Rady Lekarskiej przy okazji przyjęcia regulaminu organizacyjnego biura Wielkopolskiej Izby Lekarskiej we wrześniu 2007 r. ${ }^{13}$ Obecnie zatrudnia dwoje pracowników, a ilość spraw, którymi się zajmuje z roku na rok wzrasta.

\section{Organizacja procesu doskonalenia zawodowego przez Wielkopolską Izbę Lekarską}

Wielkopolska Izba Lekarska powstała w 1989 z inicjatywy m.in. prezesa Oddziału Poznańskiego Polskiego Towarzystwa Lekarskiego prof. Jana Hasika ${ }^{14}$. Przebyła tradycyjną drogę,

\footnotetext{
${ }^{10}$ § 3 ust. 1 uchwały nr 98/04/IV Naczelnej Rady Lekarskiej z dnia 17 grudnia 2004 r. w sprawie doskonalenia zawodowego lekarzy i lekarzy dentystów.

${ }^{11}$ § 3 ust. 1-2 uchwały nr 15/08/IV Naczelnej Rady Lekarskiej z dnia 19 września 2008 w sprawie Ośrodka Doskonalenia Zawodowego Lekarzy i Lekarzy Dentystów Naczelnej Izby Lekarskiej.

${ }^{12} \S 8$ uchwały nr 15/08/IV Naczelnej Rady Lekarskiej z dnia 19 września 2008 w sprawie Ośrodka Doskonalenia Zawodowego Lekarzy i Lekarzy Dentystów Naczelnej Izby Lekarskiej.

${ }^{13}$ Uchwała nr 46/2007 Okręgowej Rady Lekarskiej Wielkopolskiej Izby Lekarskiej z dnia 21 września 2007 r. w sprawie przyjęcia Regulaminu Organizacyjnego Biura WIL - Archiwum WIL.

${ }^{14}$ Wielkopolska Izba Lekarska. Tradycja i współczesność 1921-1999, red. A. Baszkowski, J. T. Marcinkowski, A. Zarzycki, Poznań 2000, s. 68.
} 
kiedy to pojawili się lokalni liderzy, którzy swą determinacją i zdecydowaniem doprowadzili do odtworzenia samorządu lekarsko-dentystycznego w Wielkopolsce, nawiązując do tradycji Pomorsko-Poznańskiej Izby Lekarskiej, która została zlikwidowana przez władze Polskiej Rzeczpospolitej Ludowej w 1950 r. Nie zmienia to jednak faktu, że w latach wcześniejszych pojawiały się propozycje odtworzenia samorządu lekarskiego, jednak dopiero lata osiemdziesiąte umożliwiły wyartykułowanie dążeń i włączenie ich do nurtu „solidarnościowego”. Wprowadzenie stanu wojennego spowolniło ruch oddolny, ale atmosfera końca okresu PRL i zbliżających się wyborów do Sejmu kontraktowego umożliwiła rozwinięcie idei i wcielenie jej w czyny.

I Zjazd Delegatów Wielkopolskiej Izby Lekarskiej miał miejsce 10 października 1989 r. w Collegium Anatomicum w Poznaniu. Pierwszym przewodniczącym Okręgowej Rady Lekarskiej został dr med. Piotr Dylewicz. Po uchwaleniu ustawy przez Sejm w dniu 17 maja 1989 r. i po formalnym powołaniu przez Naczelną Radę Lekarską okręgowych izb lekarskich w grudniu 1989 r. przystąpiono do dalszych czynności organizacyjnych, zarówno w kontekście uzupełniania członkostwa w organach samorządu, jak i organizacji administracji biurowej w związku z obsługą niektórych czynności urzędowych przejętych od administracji państwowej. Okręgowa Rada Lekarska, która między posiedzeniami najwyższej władzy w samorządzie tj. Okręgowego Zjazdu Lekarzy Wielkopolskiej Izby Lekarskiej, powołuje od samego początku komisje problemowe. Nie inaczej było już w I kadencji, kiedy powołano Komisję Szkolenia Medycznego, a jej przewodniczącym został dr hab. med. Andrzej Cieśliński. To właśnie ta komisja zajęła się sprawami doskonalenia zawodowego i ustawicznego podnoszenia kwalifikacji zawodowych ${ }^{15}$.

\section{Działalność Komisji Szkolenia Medycznego}

Komisja Szkolenia Medycznego, choć miała umocowanie samorządowe, musiała stanąć przed koniecznością umiejscowienia swojej roli w procesach decyzyjnych dotyczących kształcenia lekarzy i to nie tylko w prawie korporacyjnym. Dotyczyło to także poziomu ustaw i rozporządzeń wydawanych na szczeblu krajowym. Łatwiej było budować relacje lokalne i branżowe, gdzie w toku negocjacji udawało się wypracować uczestnictwo przedstawicieli izby z głosem doradczym w sprawach związanych ze specjalizacjami, programami studiów medycznych, organizacją stażu podyplomowego czy kształcenia ustawicznego. Udało się również stosunkowo szybko uczestniczyć w egzaminach $\mathrm{I}^{\circ}$ i $\mathrm{II}^{\circ}$ specjalizacji, tworzyć struktury i programy szkolenia przed- i podyplomowego oraz programy specjalizacji. Współpracowano $\mathrm{z}$ towarzystwami naukowymi, a także uczestniczono w tworzeniu Wydziału Szkolenia Podyplomowego Akademii Medycznej ${ }^{16}$. Istotnym osiągnięciem było ugruntowanie uczestnictwa przedstawicieli samorządu lekarskiego w pracach komisji konkursowych na stanowiska ordynatorów i innych fachowych stanowisk w służbie zdrowia, o czym mówił m.in. ówczesny przewodniczący Okręgowej Rady Lekarskiej Piotr Dylewicz ${ }^{17}$. Działalność przedstawicieli Komisji obejmowała również członkostwo i aktywność w strukturach Komisji Szkolenia Medycznego Naczelnej Rady Lekarskiej, do której należało 3 członków komisji z Izby Wielkopolskiej.

${ }^{15}$ Ibidem s. 67-68.

16 „Biuletyn Informacyjny Wielkopolskiej Izby Lekarskiej”, nr 1.

17 „Biuletyn Informacyjny Wielkopolskiej Izby Lekarskiej”, nr 6, Poznań, listopad-grudzień 1990, s. 9. 
W roku 1991 Komisja Szkolenia Medycznego Wielkopolskiej Izby Lekarskiej podjęła bardzo istotną decyzję kierunkową, która skutkuje swoim oddziaływaniem na następne kadencje, także tą obecną. Chodzi mianowicie o rozpoczęcie prac nad stworzeniem regulaminu udzielania pomocy finansowej na cele szkoleniowe lub naukowe. Decyzja ta doprowadzi w późniejszym okresie do przyjęcia stosownego aktu, ale jednocześnie do wydzielenia środków budżetowych na ten cel, co formalnie miało miejsce podczas obrad III Okręgowego Zjazdu Lekarzy Wielkopolskiej Izby Lekarskiej w dniu 26 kwietnia 1991 r. poprzez podjęcie uchwały nr 5 w sprawie wydzielenia części budżetu Izby na finansowanie wydatków na szkolenie medyczne. Uchwała ta przeznaczała kwotę ówczesnych 30 milionów złotych z przeznaczeniem na szkolenie podyplomowe. Ustalono, że środki te będą rozdysponowywane 2 razy do roku w drodze konkursu przeprowadzanego przez komisję powołaną przez Okręgową Radę Lekarską. Kryteria przyznawania pomocy finansowej przygotować miała Komisja Szkolenia Medycznego, która rekomendowała go do zatwierdzenia Okręgowej Radzie Lekarskiej Wielkopolskiej Izby Lekarskiej. Regulamin przyznawania lekarzom pomocy finansowej na cele szkoleniowe został przyjęty w dniu 16 listopada $1991 \mathrm{r}$. Efektem tej uchwały było przyznanie pomocy finansowej na udział w szkoleniu oraz zjazdy 15 lekarzom na łączną sumę ponad $24 \mathrm{mln} \mathrm{zf}^{18}$. Drugą uchwałą w materii doskonalenia zawodowego było wyasygnowanie przez III Okręgowy Zjazd Lekarzy Wielkopolskiej Izby Lekarskiej kolejnej kwoty $30 \mathrm{mln}$ zł na zakup subskrypcji materiałów szkoleniowych prezentowanych na taśmach wideo i magnetofonowych oraz czasopisma „New England Journal of Medicine”19. Zakupiono i użyczano członkom Wielkopolskiej Izby Lekarskiej taśmy magnetowidowe z zakresu ultrasonografii oraz problemów klinicznych związanych z zagrożeniem życia, taśmy magnetofonowe prezentujące aktualne problemy w kardiologii i taśmy video z zakresu stomatologii. Zakupy te dotyczyły także materiałów anglojęzycznych, co było przejawem wysokiego poziomu świadomości członków Komisji Szkolenia Medycznego o różnicach w poziomie wiedzy medycznej w Polsce okresu transformacji i krajach rozwiniętych. Pozytywne doświadczenia $\mathrm{z}$ realizacji pierwszych uchwał dotyczących finansowania doskonalenia zawodowego z budżetu Wielkopolskiej Izby Lekarskiej spowodowały coroczny wzrost tych środków i większe zainteresowanie środowiska i jednostek ochrony zdrowia powiększającą się wideoteką.

W II kadencji nastąpiła zmiana przewodniczącego Komisji Szkolenia Medycznego, którym został dr n. med. Michał Rólski. Dostrzegana jest również zmiana koncepcji funkcjonowania samej komisji. Poza dotychczasowymi działaniami na rzecz refundacji kosztów udziału w kursach i sympozjach naukowych czy pracach badawczych, Komisja Szkolenia Medycznego Wielkopolskiej Izby Lekarskiej, podejmuje współpracę z instytucjami akademickimi na rzecz organizacji wspólnych przedsięwzięć szkoleniowych w formie podyplomowej. I tak w 1994 r. odbyły się kursy poświęcone m.in. „Doraźnej pomocy w stanach zagrożenia życia” czy „Terapii nadciśnienia tętniczego" ${ }^{20}$. Jednocześnie rozpoczęto prace nad wykorzystaniem nowych narzędzi elektronicznych do celów szkoleniowych. Komisja Szkolenia Medycznego dofinansowywała również szkolenia organizowane przez delegatury Wielkopolskiej Izby Lekarskiej m.in. w Śremie, Koninie i Gnieźnie. Efektem działań na szeroką skalę było niemal $100 \%$ wykonanie przyznanego budżetu, który wynosić miał 80 tys. zł. Wzrost ilości szkoleń

\footnotetext{
${ }^{18}$ Sprawozdanie Komisji Szkolenia Medycznego na IV Okręgowy Zjazd Lekarzy Wielkopolskiej Izby Lekarskiej - Archiwum WIL.

${ }^{19}$ Uchwała nr 6/1991 III Okręgowego Zjazdu Lekarzy Wielkopolskiej Izby Lekarskiej z dnia 26 kwietnia 1991 r. w sprawie wydzielenia części budżetu Izby na finansowanie wydatków na szkolenie medyczne - Archiwum WIL.

${ }^{20}$ Sprawozdanie z działalności Komisji Szkolenia Medycznego za rok 1994 - Archiwum WIL.
} 
i zakres ich dofinansowywania z budżetu Izby spowodował odsunięcie od realizacji kontynuacji zakupu wideoteki do celów szkoleniowych. Skupiono się jednak na wykorzystaniu Internetu i sprzętu komputerowego do celów szkoleniowych. Właśnie ten cel był obecny w dążeniach członków Komisji Szkolenia Medycznego. Jednak sztywny poziom budżetu na cele kształcenia w ramach budżetu komisji oraz koncepcja kierunkowa, która mówiła o konieczności redystrybucji środków finansowych bezpośrednio do środowiska spowodował odłożenie w czasie działań inwestycyjnych i twardych na rzecz miękkich, takich jak refundacje i dofinansowywanie poszczególnych imprez o charakterze naukowym i dydaktycznym, które realizowane były na podstawie uchwały nr 11/95 VIII Okręgowego Zjazdu Lekarzy Wielkopolskiej Izby Lekarskiej w Poznaniu z dnia 21 kwietnia 1995 r. w sprawie zasad przyznawania lekarzom pomocy na cele szkoleniowe. Zasady te umożliwiały refundację kosztów udziału do kwoty 150 zł w kursach i szkoleniach i do kwoty 500 zł za udział w obowiązkowych kursach atestacyjnych w trakcie specjalizacji. Umożliwiała również dopłatę w kwocie do $300 \mathrm{zł}$ do stażu specjalizacyjnego ${ }^{21}$. Taka pomoc przysługiwała lekarzom raz do roku, a warunkiem było dostarczenie rachunków potwierdzających uczestnictwo w kursach i szkoleniach.

III kadencja to zmiany organizacyjne w komisji. Zmienia ona nie tylko nazwę na Komisję ds. Kształcenia Medycznego. Zmienia się również jej przewodniczący. Zostaje nim dr med. Marek Popielarz. Dodatkowo XII Okręgowy Zjazd Lekarzy Wielkopolskiej Izby Lekarskiej w Poznaniu w dniu 31.03.1998 r. zmienia zasady udzielania pomocy finansowej na cele kształcenia medycznego. Najważniejszą z nich jest umożliwienie otrzymywania zwrotu poniesionych nakładów na doskonalenie zawodowe dla członków Wielkopolskiej Izby Lekarskiej w trakcie specjalizacji. Utrzymano jednorazową refundację, którą ustalono na maksymalnym poziomie 200 zł. Dla zwiększenia przejrzystości procedur wprowadzono również druki, na których składać należało wnioski o refundację. Wprowadzała również możliwość odwołania się do Okręgowej Rady Lekarskiej od negatywnej decyzji Komisji ds. Kształcenia Medycznego w sprawie przyznania refundacji kosztów uczestnictwa w kształceniu ustawicznym ${ }^{22}$. W 1998 r. budżet Komisji po raz pierwszy wynosił 100000 zł, ale został wykorzystany jedynie $\mathrm{w}$ połowie.

W III kadencji zauważyć można lepszą współpracę z Akademią Medyczną w Poznaniu, co skutkuje podpisaniem w dniu 21 maja 1998 r. porozumienia o współpracy pomiędzy Wielkopolską Izbą Lekarską a Akademią Medyczną w Poznaniu. Umowa ta ma zasadnicze znaczenie $\mathrm{z}$ uwagi na fakt potwierdzenia w niej przez obu sygnatariuszy wiodącej roli samorządu lekarskiego w procesie kształcenia podyplomowego lekarzy i lekarzy dentystów. Komisja dążyła również do udostępnienia członkom Wielkopolskiej Izby Lekarskiej zasobów bibliotecznych Akademii Medycznej w Poznaniu poprzez Internet. Jednym ze środków do tego celu miało być w tej sytuacji dofinansowanie przez Izbę XVII Konferencji Problemowej Bibliotek Medycznych. W 1999 r. zwiększono limit pomocy finansowej do kwoty 300 zł rocznie ${ }^{23}$.

${ }^{21}$ Art. 2 ppkt a)-c) uchwały nr 11/95 VIII Okręgowego Zjazdu Lekarzy Wielkopolskiej Izby Lekarskiej w Poznaniu z dnia 21 kwietnia 1995 r. w sprawie zasad przyznawania lekarzom pomocy na cele szkoleniowe-Archiwum WIL.

${ }^{22}$ § 1 uchwały nr 8/98 XII Okręgowego Zjazdu Lekarzy Wielkopolskiej Izby Lekarskiej w Poznaniu z dnia 31 marca 1998 r. w sprawie zasad udzielania pomocy finansowej na cele kształcenia medycznego-Archiwum WIL.

${ }^{23}$ § 1 uchwały nr 10/99 XIII Okręgowego Zjazdu Lekarzy Wielkopolskiej Izby Lekarskiej w Poznaniu z dnia 23 marca 1999 r. w sprawie zmiany uchwały nr 8/99 XII Okregowego Zjazdu Lekarzy Wielkopolskiej Izby Lekarskiej w Poznaniu z dnia 31 marca 1998 r. w sprawie udzielenia pomocy finansowej na cele kształcenia medycznego - Archiwum WIL. 
Duże zainteresowanie środowiska lekarskiego możliwością otrzymania zwrotu kosztów uczestnictwa w kursach doskonalących spowodowało powrót w roku 2001 do wcześniejszej koncepcji o refundacji wydatków na medyczne doskonalenie w różnych formach kształcenia podyplomowego. I tak refundacja przysługiwała:

a) specjalizującym się lekarzom odbywających szkolenia i staże specjalizacyjne do wysokości $600 \mathrm{zl}$;

b) lekarzom w trakcie stażu podyplomowego szkolących się w formach nieobjętych programem stażu do wysokości $100 \mathrm{zl}$, przyznane jednokrotnie w trakcie stażu;

c) lekarzom po zakończeniu stażu podyplomowego, ale przed rozpoczęciem specjalizacji do wysokości $200 \mathrm{zł;}$

d) lekarzom, którzy nie są pracownikami Akademii Medycznej ani słuchaczami studiów doktoranckich, uzyskujących stopień naukowy doktora nauk medycznych do wysokości $1500 \mathrm{zł}^{24}$.

Przyjęte w 2001 r. zasady utrzymały się w mocy do 1 kwietnia 2006 r., kiedy to XXV Okręgowy Zjazd Lekarzy Wielkopolskiej Izby Lekarskiej, na wniosek Komisji ds. Młodych Lekarzy, przyjął uchwałę nr 12/2006, która nowelizowała zasady udzielania pomocy finansowej na cele kształcenia medycznego i wprowadzała możliwość corocznego ustalania przez Komisję ds. Kształcenia Medycznego ryczałtowej stawki za każdy dzień pobytu na szkoleniu dla osób, które nie mogą udokumentować poniesionych wydatków fakturami i rachunkami, a musiały dojechać na kurs ponad $35 \mathrm{~km}$.

IV kadencja i praca Komisji ds. Kształcenia Medycznego musiała ulec rozszerzeniu. Komisja bowiem otrzymała nowe zadania w postaci nadzoru nad obligatoryjnością uzyskiwania punktów edukacyjnych przez środowisko lekarskie oraz koniecznością nadzoru nad jakością kształcenia podyplomowego poprzez prowadzenie rejestru podmiotów uprawnionych do prowadzenia kursów i szkoleń podyplomowych dla lekarzy i lekarzy dentystów w Wielkopol$\mathrm{sce}^{25}$. Połączenie tych nowych czynności z dotychczasowymi obowiązkami, do których należało ustalanie miejsc stażowych, usytuowało Komisję ds. Kształcenia Medycznego jako jedną z najistotniejszych komisji problemowych powoływanych przez Okręgową Radę Lekarską. Dodatkowo Rada Okręgowa Wielkopolskiej Izby Lekarskiej zdecydowała, że Komisja ds. Kształcenia zajmować się będzie również Współpracą Międzynarodową, co skutkowało powołaniem w ramach komisji Zespołu ds. Współpracy Międzynarodowej. Rozwiązanie to przetrwało jednak jedynie okres 4 lat bowiem w 2006 r., kiedy Okręgowa Rada Lekarska Wielkopolskiej Izby Lekarskiej ustalała nowy skład komisji zdecydowała się wrócić do pierwotnej koncepcji, która funkcjonowała w samorządzie przez lata i pozostawić w gestii komisji jedynie sprawy kształcenia i doskonalenia zawodowego. Okręgowa Rada Lekarska powołała w dniu 3 marca 2006 r. Komisję ds. Kształcenia, a jej przewodniczenie powierzyła dr n. med. Aldonie Pietrysiak. Komisja kontynuowała sprawy w zakresie stażu podyplomowego, rozliczania ewidencji doskonalenia zawodowego, współpracy z Centrum Egzaminów Medycznych, prowadzenia rejestru podmiotów kształcących oraz refundowała koszty podnoszenia kwalifikacji zawodowych dla członków izby. Niemniej jednak członkostwo w Unii Europejskiej otworzyło przed samorządem nową perspektywę, jaką była możliwość pozyskania zewnętrznych środków finansowych na prowadzenie kursów podnoszących kwalifikacje

\footnotetext{
${ }^{24} \S 2$ ust. 1 ppkt a)-d) uchwały nr 8/2001 XV Okręgowego Zjazdu Lekarzy Wielkopolskiej Izby Lekarskiej w Poznaniu z dnia 4 kwietnia 2001 r. w sprawie zasad udzielania pomocy finansowej na cele kształcenia medycznego - Archiwum WIL.

${ }^{25}$ Sprawozdanie Komisji Kształcenia i Wspótpracy Międzynarodowej za 2003 r. - Archiwum WIL.
} 
zawodowe. Jeszcze na przełomie lat 2005/2006 Wielkopolska Izba Lekarska opracowała „Program rozwoju i doskonalenia zawodowego lekarzy, członków Wielkopolskiej Izby Lekarskiej”, który został złożony w ramach konkursu ogłoszonego dla Sektorowego Programu Operacyjnego Rozwój Zasobów Ludzkich 2004-2006. Kurs ten obejmować miał następującą tematykę:

a) aktualizacja wiedzy z zakresu podstawowych dziedzin medycyny;

b) orzecznictwo;

c) kształcenie językowe o profilu medycznym;

d) stomatologia;

e) wczesna diagnostyka onkologiczna;

f) podstawy profilaktyki chorób przewlekłych o znaczeniu społecznym z elementami promocji zdrowia;

g) zarządzanie i organizacja bieżącej działalności placówek medycznych ${ }^{26}$.

Rozmach projektu, w którym uczestniczyć miało ponad 1200 osób, niestety nie przełożył się na pozytywną decyzję instytucji oceniającej. Nie spowodowało to jednak zaniechania działań na rzecz pozyskania środków unijnych na kształcenie. W kolejnych latach Wielkopolska Izba Lekarska również składała wnioski o dotację z Programu Operacyjnego Kapitał Ludzki, w których proponowała szkolenia z czterech bloków tematycznych: onkologia i diagnostyka onkologiczna, ratownictwo medyczne, toksykologia i specjalistyczny, medyczny język angielski. Do końca roku 2009 nie udało się jednak uzyskać wsparcia.

Komisja cały czas patronuje, dofinansowuje i sama organizuje kursy doskonalenia zawodowego. Aktywną rolę w działalności szkoleniowej przejęły również delegatury Wielkopolskiej Izby Lekarskiej. Szczególnie aktywne są środowiska lekarzy dentystów z Delegatury Ostrowsko-Krotoszyńskiej oraz Delegatury Kaliskiej.

W roku 2008 rozpoczęły się kolejne rozmowy o współpracy z Uniwersytetem Medycznym im. Karola Marcinkowskiego w Poznaniu na temat odnowienia współpracy, która uległa spowolnieniu. Ich efektem był m.in. przeprowadzony wspólnie we wrześniu 2008 r. kurs ze „Zdrowia publicznego”, w którym jednorazowo uczestniczyło ponad 100 lekarzy. Sukces wspólnego przedsięwzięcia spowodował podpisanie kolejnej umowy o współpracy władz izby i uniwersytetu, co miało miejsce w dniu 19.03.2009 r. ${ }^{27}$

Analizując środki finansowe przekazywane corocznie przez Okręgowy Zjazd Lekarzy w uchwalanym budżecie należy zauważyć, że ich wysokość stanowi istotną pozycję w wydatkach, które potocznie nazywa się wydatkami „,środowiskowymi”, tzn. takimi, które mają wracać bezpośrednio do lekarzy. Pierwsze wyodrębnienie pieniędzy oznaczonych na cele doskonalenia zawodowego miało miejsce w 1991 r. Od tego roku każdy budżet dedykuje część środków pieniężnych na ten cel i każdorazowo zarówno władze komisji, jak i władze izby dążą przynajmniej do zachowania poziomu kwot z roku poprzedniego, choć zaobserwować należy stały wzrost ilości środków. Od roku 1999 poziom finansów na kształcenie przekracza 100000 zł rocznie, z wyjątkami przypadającymi na lata 2002-2005, kiedy to izba dokonywała m.in. zakupów inwestycyjnych w postaci nowej siedziby w Poznaniu oraz w Pile. Niemniej jednak od roku 2006 kwoty te znacznie przekraczają poziom 150000 zł rocznie i co należy podkreślić, są one konsumowane na poziomie przekraczającym 95\% wykorzystania rocznego budżetu.

\footnotetext{
${ }^{26}$ Archiwum WIL.

${ }^{27}$ Sprawozdanie z działalności Komisji ds. Kształcenia Medycznego za rok 2009 - Archiwum WIL.
} 


\section{Współpraca z innymi instytucjami i organizacjami}

Należy także nie zapominać, że w realizacji zadań poświęconych ustawicznemu kształceniu środowiska lekarskiego nie można pominąć współpracy z innymi, branżowo zbliżonymi instytucjami i organizacjami, które uczestniczą w tych przedsięwzięciach. Przywołana wcześniej współpraca z Uniwersytetem Medycznym im. Karola Marcinkowskiego w Poznaniu, potwierdzona podpisanymi porozumieniami o współpracy stanowi tylko jedną z instytucji, z którą Wielkopolska Izba współpracuje. Obecna jest również kooperacja z towarzystwami naukowymi, szczególnie lekarskimi, takimi jak Towarzystwo Chirurgów Dziecięcych, Polskie Towarzystwo Lekarskie, ale także Polskie Towarzystwo Przyjaciół Nauk. Najczęściej ta współpraca przejawia się poprzez współfinansowanie imprez naukowych, które organizują towarzystwa. Przykładami takiej współpracy było przekazanie środków finansowych na XIV Ogólnopolski Zjazd Medycyny Komunikacyjnej czy warsztaty Chirurgów Dziecięcych poświęcone Uropatiom Zastoinowym ${ }^{28}$. Innym polem kooperacji było dofinansowywanie materiałów edukacyjnych dla uczestników Konferencji Naukowo-Szkoleniowej Oddziału Poznańskiego Polskiego Towarzystwa Stomatologicznego i Ogólnopolskiej Konferencji Sekcji Protetyki Polskiego Towarzystwa Stomatologicznego ${ }^{29}$.

Wielkopolska Izba Lekarska stara się również nie zapominać o lekarzach polskiego pochodzenia, którzy nie mieszkają na terenie kraju, ale chętnie uczestniczą w spotkaniach naukowych w Polsce. Takie wsparcie udzielane jest lekarzom z Białorusi, Mołdawii czy Ukrainy. W latach 2002-2004 szczególnie aktywna była współpraca z Polskim Towarzystwem Lekarskim w Baranowiczach czy Wielkopolskim Oddziałem Stowarzyszenia Wspólnota Polska.

Nie można również zapomnieć o międzynarodowej aktywności izby w zakresie umożliwienia podnoszenia kwalifikacji zawodowych podczas zagranicznych staży i kursów. W latach 90-tych XX wieku kontynuowano, już oficjalnie, rozpoczętą jeszcze w latach PRL współpracę z niemiecką fundacją „Hilfe für Polen”, która zajmowała się umożliwianiem odbycia stażów w niemieckich klinikach o dużym poziomie wyspecjalizowania. Dodatkowym, bardzo ciekawym doświadczeniem było umożliwienie uczestnikom tych staży zamieszkania u niemieckich rodzin lekarskich, co z pewnością pozostawało w pamięci. Taka współpraca była również podjęta z francuską fundacją Ille-et-Vilaine-Pologne, która zajmowała się organizowaniem miejsc stażowych w Rennes, a patronat nad tym przedsięwzięciem obją miejscowy Uniwersytet ${ }^{30}$. Kolejnym polem współpracy jest współorganizacja przedsięwzięć szkoleniowych z podmiotami zewnętrznymi, firmami szkoleniowymi, które w swojej codziennej działalności zajmują się odpłatną organizacją kursów doskonalących.

Prowadzenie przez samorząd lekarski działalności w zakresie doskonalenia zawodowego swoich członków obejmującej zarówno organizację tego procesu, jak i nadzór nad jego wykonywaniem przez lekarzy jest jedną z najlepszych metod sprawowania pieczy nad wykonywaniem zawodu przez lekarzy. Obok systemu odpowiedzialności zawodowej jest głównym narzędziem, za pomocą którego korporacja lekarska dba o jakość usług świadczonych społeczeństwu przez medyków. Dotychczasowa działalność izb lekarskich w tej materii pozwala sądzić, że idąc do lekarza zetkniemy się z dobrze przygotowanym do pracy specjalista, który zaaplikuje nam terapię opartą o najnowsze osiągnięcia nauk medycznych.

\footnotetext{
${ }^{28}$ Sprawozdanie Komisji Szkolenia Medycznego za rok 1995 - Archiwum WIL.

${ }^{29}$ Sprawozdanie Komisji Kształcenia Medycznego za rok 2000 - Archiwum WIL.

${ }^{30}$ Sprawozdanie Komisji Kształcenia i Wspótpracy Międzynarodowej za rok 2004 - Archiwum WIL.
} 


\section{Summary}

\section{The activity of the professional self-governing body of doctors in the area of professional improvement - based on the example of the Wielkopolska Medical Chamber}

The issue of the continuous improvement of professional qualifications by medical doctors is of utmost importance both from the point of view of doctors and their patients. Acquiring new knowledge and skills is an important element of a doctor's professional career. A doctor who raises his qualifications guarantees better medical care for a patient. The professional self-governing body of doctors constitutes a significant element in the postgraduate education of doctors. It participates in the education of interns and in the procedure of acquiring the title of specialist. It also supervises and organizes the process of doctors' mandatory continuous education. A majority of the tasks related to doctors' professional education is performed by regional chambers. The Wielkopolska Medical Chamber organizes training sessions and courses for its members, which are one of the forms of fulfilling the requirement of professional improvement, reimburses a portion of the costs borne by the doctors in connection with improving their professional qualifications, and it establishes cooperation with domestic and foreign academic institutions to provide doctors from Wielkopolska with an opportunity to partake in training. These activities of the medical association, combined with the organs of professional liability of doctors, allow the patients to hope that when visiting a doctor they encounter a specialist who will take the utmost care of them. 